\title{
EVALUATION OF ALFALFA HAY AND SILAGE IN COMPLETE DIETS FOR LACTATING GOATS
}

\author{
H.M. El-Shabrawy ${ }^{1}$, A.Z. Mehrez ${ }^{2}$ and E.I. Shehata ${ }^{1}$
}

1- Animal Production Research Institute, A.R.C., Ministry of Agriculture., Dokki, Giza, Egyp, 2- Animal Production Department, Faculty of Agriculture, Mansoura University, Mansoura, Egypt

\section{SUMMARY}

Third and fourth cuts of alfalfa forage were conserved as hay or ensiled either untreated or treated with $1.3 \mathrm{~g}$ of $\mathrm{HCHO} / 100 \mathrm{~g}$ of $\mathrm{CP}$ and fed to lactating Zariabi goats (three groups, 6 each group).

The obtained results indicated that silage treated with $\mathrm{HCHO}$ had the lowest $\mathrm{pH}$ and concentrations of $\mathrm{NPN}, \mathrm{NH}_{3}$, butyric acid and protein solubility, while acetic acid concentration increased. The improvements in the digestibilities of nutrients reflected better feeding values in terms of TDN, DCP and NEl for diet containing treated-AS than AH or AS. Rumen $\mathrm{pH}$ and concentration of VFA were similar for all diets.

Although dry matter intake was comparable, yields of milk, 4\% FCM and its component were higher when treated silage were fed. Milk NPN concentration and rumen $\mathrm{NH}_{3}-\mathrm{N}$ concentration were lower on treated-silage diet. On the other hand, yields of true protein- $N, C N, N C N$ and whey- $N$ in milk were higher for goats fed treated-silage diet. This indicated efficiency of the protection and/or better synchronization between availability of energy and release of $\mathrm{NH}_{3}-\mathrm{N}$. Plasma concentration urea- $N$ was decreased when the HCHO-treated silage, whereas, concentrations total protein and albumin were increased.

It could be concluded that formaldehyde treatment effectively improved utilization of nutrients in alfalfa silage by lactating goats based on better fermentation characteristics during ensiling and in the rumen and improved feeding values. In addition, formaldehyde treatment could be recommended for the alfalfa silage to improve milk production and its components.

Keywords: Alfalfa, hay, silage, goats, milk production, milk composition, milk protein fractions

\section{INTRODUCTION}

Alfalfa forage, conserved as hay or silage, is a major dietary component for lactating animals. As much as 75 to $87 \%$ of the total $\mathrm{N}$ present in alfalfa silage may be NPN (Muck, 1987 and Broderick et al., 1990). Moreover, alfalfa protein is subjected to extensive degradation during ensiling, particularly that in alfalfa silage (AS), is poorly utilized because of its extensive degradation in the rumen (Merchen and Satter, 1983) and Hristov et al., 2001), solubility in vitro (Nagel and Broderick, 1992), and excessive production of $\mathrm{NH}_{3}$ in the rumen (Vagnoni and Broderick, 1997), which suggest that conservation of alfalfa as silage may reduce ruminal protein

Issued by The Egyptian Society of Animal Production 
escape, synthesis of ruminal microbial $\mathrm{CP}$, or both, relative to conservation of alfalfa as hay. The NRC (1989) and Beauchemin et al. (1997) reported that the rumen undergradable protein (RUP) content of alfalfa hay (AH) was $18 \%$ greater than that of its silage (AS).

Formaldehyde reduces protein degradability by forming cross-links between protein chains and has antimicrobial properties that may alter the bacterial population and fermentation pattern of silage (Woolford, 1975).

Post ruminal infusion of protein (as casein) in lactating cows fed a diet containing $98 \%$ of DM from AS increased milk and protein yields by 5.5 and $0.18 \mathrm{~K} / \mathrm{d}$, respectively and infusion of energy (as glucose) did not increase yield (Dhiman et al., 1993). These results indicated that protein, but not energy, was the first limiting nutrient for milk yield in cows fed diets high in AS. For lactating dairy cows fed AH or AS as the sole forage, addition of 3\% fish meal, a high source of RUP, increased milk protein yield by 30 and $100 \mathrm{~g} / \mathrm{d}$, respectively (Broderick, 1995).

Poor performance on diets high in AS might result from inadequate capture of dietary $\mathrm{N}$ as absorbable protein. Also, lactating cows fed formaldehyde-treated AS or formic acid-treated AS as the sole forage, increased milk yield and milk protein yield by $3.3,0.06,3.40,0.11 \mathrm{~kg} / \mathrm{d}$, respectively than those fed untreated silage (Nagel and Broderick, 1992).

Increased dry matter intake and $\mathrm{N}$ retention have been reported in sheep (Barry et al., 1978), dairy heifers (Waldo et al., 1971), and dairy cows (Nagel and Broderick, 1992) fed treated-AS.

The objective of this work was to study the effect of different forms of alfalfa as hay, untreated silage and formaldehyde-treated silage in lactating goat's ration on milk yield, milk components yield, milk protein fractions, nutrients digestibility, some rumen liquor parameters and plasma metabolite concentrations. In addition, the effect of formaldehyde on silage fermentation and protein solubility were determined.

\section{MATERIALS AND METHODS}

The current investigation was carried out at El-Serw Experimental Station, Animal Production Research Institute, Agricultural Research Center, Ministry of Agriculture, Egypt.

\section{Preparation of Experimental diets:}

Alfalfa was grown at El-Serw Agriculture Research Station. Third and fourth cuts in second year before bloom were used in this experiment. The harvested plants were divided into two parts. One part was wilted to approximately $85 \% \mathrm{DM}$, chopped to a length of $5 \mathrm{~cm}$ and conserved in a stack and stored under shelter. The other part of alfalfa was allowed to wilt to approximately 33\% DM and then ensiled in double plastic bags $(130 \times 80 \mathrm{~cm})$. Forage was ensiled untreated or treated with formaldehyde (1.3 $\mathrm{g}$ of $\mathrm{HCHO} / 100 \mathrm{~g}$ of $\mathrm{CP})$.

\section{Experimental animals and their management:}

Eighteen lactating Zaraibi goats in mid-lactation were balanced for body weight, milk yield, days after calving and parity. The animals were divided into 3 groups and received one of 3 experimental diets. Diets were formulated to contain (\% of DM) $50 \%$ alfalfa hay or silage (Table 1 ). The diets were prepared once daily as a total 
mixed ration and the animals were fed twice daily. The experimental diets were formulated and offered in quantities to cover their requirements calculated according to NRC (1981). Diets were calculated every two weeks based on the average milk production and body weight. Animals of each group were housed in stalls $(3 \times 3 \mathrm{~m})$ and fed in groups. Fresh and clean drinking water was available all times. The experiment began after 10 days of adaptation to the different rations and lasted 12 weeks.

Table 1. Formulation of the experimental diets (\% of DM)

\begin{tabular}{lccc}
\hline & \multicolumn{3}{c}{ Experimental diets* } \\
\cline { 2 - 4 } Ingredients & AH & AS & FAS \\
\hline Alfalfa as: & 50 & -- & -- \\
$\quad$ Hay (Chopped) & -- & 50 & -- \\
$\quad$ Untreated silage & -- & -- & 50 \\
$\quad$ Formaldehyde-treated silage & 22.50 & 22.50 & 22.50 \\
Yellow corn & 11.00 & 11.00 & 11.00 \\
Undecorticated cotton seed meal & 14.0 & 14.00 & 14.00 \\
Wheat bran & 1.25 & 1.25 & 1.25 \\
Limestone & 0.75 & 0.75 & 0.75 \\
Salt & 0.50 & 0.50 & 0.50 \\
Minerals and vitamins mixture** & &
\end{tabular}

* AH: Alfalfa hay, AS: Untreated alfalfa silage FAS: Alfalfa silage treated with formaldehyde.

** Each Kg contained P, 40 g, Ca, 50 g, Mg. 50 g, Mn, 4.5 g, S, 12 g, Fe, 7 g, Cu, 2 g, Se, 12 $\mathrm{mg}$, Co, $50 \mathrm{mg}$, vitamin A, $2000000 \mathrm{IU}$, vitamin D, $20000 \mathrm{IU}$ and vitamin E, $20 \mathrm{mg}$ (Biomix 33, Produced by Biochema, A.R.E., Cairo).

Animals were hand milked twice daily and milk yield of individual animals was recorded at each milking. Fat corrected milk (4\% FCM) for each animal was calculated using the formula of Gaines and Overman (1938). Milk was sampled biweekly form two consecutive milkings, and composited according to milk yield. Composite milk samples were analyzed for contents of total solids (TS), ash, fat, total nitrogen $(\mathrm{TN})$, non-casein nitrogen $(\mathrm{NCN})$, and non-protein nitrogen (NPN).

Total solids in milk were determined by drying at $105^{\circ} \mathrm{C}$ for 4 hours to a constant weight, milk fat was analyzed following the Gerber method (British Standard Institution's Method, 1955), and protein was analyzed using the Kjeldahl method (N x 6.38). Lactose was determined by difference after ashing in a muffle furnace (Model RHF, 1200 , England) at $750^{\circ} \mathrm{C}$ for 4 hours.

Solids-not fat (SNF) were calculated as the difference between TS and fat. Noncasein nitrogen $(\mathrm{NCN})$ was determined by Kjeldahl analysis of the filtrate by using Whatman paper No. 42 after precipitation with $10 \%$ acetic acid and $1 \mathrm{~N}$ sodium acetate (Ling, 1963). Non-protein nitrogen (NPN) was determined by Kjeldahl analysis of the filtrate by using Whatman paper No. 42 after precipitation with $15 \%$ trichloroacetic acid, TCA (Ling, 1963).

Casein-N was calculated as the difference between $\mathrm{TN}$ and $\mathrm{NCN}$, true protein-N was calculated as the difference between TN and NPN. Whey N was calculated as the difference between true protein-N and casein-N. Formaldehyde in the produced milk was assessed using Nash's reagent according to Naiem (1999). 


\section{Metabolism trail:}

Metabolism trials were carried out at the end of the feeding experiment using the 3 animals of each group to determine the digestion coefficients and nutritive values of the tested rations used in the feeding trial. Fecal samples were gripped from the rectum of each animal twice daily during the collection period (5 days). Acid insoluble ash (AIA) was used as a natural marker (Van Keulen and Young, 1977).

Samples of alfalfa silage, chopped alfalfa hay and concentrate mixture were collected weekly throughout the experiment. Dry matter was assayed after the samples were ground through a $1 \mathrm{~mm}$ screen hammer mill and dried at $105^{\circ} \mathrm{C}$ for 3 hours except those of silages and feces were first dried at $60^{\circ} \mathrm{C}$ for 48 hours and analyzed for ash, crude fiber, crude protein, ether extract according to AOAC (1980).

\section{Alfalfa silage quality determination:}

Samples of alfalfa silage were taken during the experimental period ( 4 samples within 12 weeks) and kept frozen at $-20^{\circ} \mathrm{C}$ until analysis. Silage samples were thawed, then extracted with distilled water and $\mathrm{pH}$ was measured immediately using battery operated $\mathrm{pH}$ meter. Water extracts were analyzed for organic acids fractions by gas liquid chromatograph (GLC). Extract $(20 \mathrm{ml})$ was deproteinized using $5 \mathrm{ml}$ of $25 \%(\mathrm{wt} / \mathrm{vol})$ TCA. The TCA extracts were analyzed for $\mathrm{NH}_{3}-\mathrm{N}$ (Conway and O'Mally, 1957) and NPN (Muck, 1987).

\section{Rumen fluid parameters:}

During the last week of the experimental period, rumen fluid samples were taken from four animals in each group just before offering morning meal and 4 hours postfeeding using stomach tube. Rumen-fluid $\mathrm{pH}$ was measured immediately on a fresh aliquot using battery operated $\mathrm{pH}$ meter, then samples were filtered through two layers of surgical gauze, acidified with $1.0 \mathrm{ml}$ of $\mathrm{H}_{2} \mathrm{SO}_{4}(50 \% \mathrm{v} / \mathrm{v})$ to retard ammonia and kept frozen at $-20^{\circ} \mathrm{C}$ until analysis of $\mathrm{NH}_{3}-\mathrm{N}$ (Conway and O'Mally, 1957) and total volatile fatty acids (Warner, 1964). Twenty milliliters of strained rumen fluid were prepared for volatile fatty acids fractions analysis by GLC.

\section{Blood parameters:}

During the last week of the experimental period, blood samples were collected in heparinized test tubes from the jugular vein from three animals of each group before morning feeding and 4 hours post-feeding. Blood samples were centrifuged immediately at 3500 revolution per minute (rpm) for 15 minutes to separate blood plasma and stored at $-20^{\circ} \mathrm{C}$ until further analysis. Blood plasma was analyzed for urea-N (Patton and Crouch, 1977), total protein (Peters, 1968), and albumin (Webster, 1974). Globulin concentration was calculated by difference (Total proteinalbumin).

\section{Statistical analysis:}

Data were subjected to statistical analysis by the computer program of SAS (1996) using the General Linear Model (GLM). Means were compared according to Duncan/s Multiple Range Test at 0.05 level (Duncan, 1955). 


\section{RESULTS AND DISCUSSION}

\section{Chemical composition:}

Formulation of the experimental diets and the chemical composition of the ingredients used to formulate the total mixed rations are presented in Tables 1 and 2. The chemical composition of the ingredients were within the normal published ranges (Abu-Raya, 1967 and Broderick, 1995). However, OM, CF, and NFE content of alfalfa silage were relatively greater than those of alfalfa hay $(\mathrm{AH})$.

Table 2. Chemical composition of the tested ingredients and the experimental diets

\begin{tabular}{|c|c|c|c|c|c|c|c|}
\hline \multirow[t]{2}{*}{ Items } & \multirow{2}{*}{$\begin{array}{l}\mathrm{DM} \\
(\%)\end{array}$} & \multicolumn{6}{|c|}{ Chemical composition on DM basis $(\%)$} \\
\hline & & $\mathrm{OM}$ & $\mathrm{CP}$ & $\mathrm{EE}$ & $\mathrm{CF}$ & NFE & Ash \\
\hline \multicolumn{8}{|l|}{ Alfalfa as: } \\
\hline Hay & 88.14 & 86.15 & 18.00 & 2.57 & 25.65 & 39.93 & 13.85 \\
\hline Untreated silage & 33.78 & 88.70 & 18.23 & 2.96 & 23.55 & 43.96 & 11.30 \\
\hline $\begin{array}{l}\text { Formaldehyde- } \\
\text { treated silage }\end{array}$ & 33.53 & 88.47 & 18.36 & 3.03 & 22.73 & 44.35 & 11.53 \\
\hline Yellow corn & 88.29 & 98.06 & 9.04 & 2.86 & 2.91 & 83.25 & 1.94 \\
\hline $\begin{array}{l}\text { Undecorticated } \\
\text { cotton seed meal }\end{array}$ & 90.05 & 94.30 & 24.43 & 5.35 & 28.72 & 38.80 & 5.70 \\
\hline Wheat bran & 88.06 & 94.76 & 13.31 & 3.76 & 9.72 & 67.97 & 5.24 \\
\hline \multicolumn{8}{|c|}{ Calculated chemical composition of the tested diets } \\
\hline $\mathrm{AH}$ & 100 & 88.77 & 15.58 & 3.04 & 17.99 & 52.16 & 11.23 \\
\hline AS & 100 & 90.05 & 15.69 & 3.24 & 16.95 & 54.17 & 9.95 \\
\hline FAS & 100 & 89.93 & 15.76 & 3.27 & 16.53 & 54.37 & 10.07 \\
\hline
\end{tabular}

\section{Fermentation characteristics and $N$ solubility:}

The results in Table 3 indicated that the treatment of alfalfa silage with formaldehyde tended to cause a high desirable fermentation as indicated by the lower $\mathrm{pH}$ and butyric acid and higher lactic acid content compared to untreated silage. The results are in agreement with previous reports (McDonald and Edwards, 1976, Nagel and Broderick, 1992). Treated silage with formaldehyde was most effective in preventing protein solubility, probably by rapidly decreased $\mathrm{pH}$ and inhibiting plant proteases. Reduced protein solubility was demonstrated by the lower NPN, $\mathrm{NH}_{3}$ in FAS versus AS. Similar results have been reported (Barry et al., 1978).

Formaldehyde treatment of silage tended to decrease $\mathrm{NPN}$ and $\mathrm{NH}_{3}$ by 20 and $50 \%$, respectively compared with those of untreated silage. Broderick et al. (1990) reported that alfalfa ensiled with 30 to $55 \%$ DM contained 62 to $76 \%$ NPN, mean NPN in the present trial was $39 \%$ of total N. Messman et al. (1994) observed that drying fresh alfalfa to $\mathrm{AH}$ reduced the amount of total soluble protein that was identifiable electrophoretically by about $25 \%$ and ensiling reduced it by more than $90 \%$.

\section{Digestion coefficients and nutritive values:}

The results of digestibility and feeding values are presented in Table 4. It was clear that there were significant differences $(\mathrm{P}<0.05)$ among means of nutrients digestibility except EE digestibility of all the tested diets. The highest values for all 
nutrient digestibility was those of diet FAS and the lowest values were of diet AH. The FAS diet was higher by about $4.2 \%$ or $2.9 \%$ for CP digestibility than diets AS or $\mathrm{AH}$, respectively. The improvement in $\mathrm{CP}$ digestibility may be related to formaldehyde treatment as a protection method of protein, hence, reducing protein solubility (Table 1) and degradability in the rumen and there for provided more dietary protein for digestion and absorption in the small intestine, which is probably is better than of microbial protein (Nagel and Broderick, 1992, Atwal et al., 1995 and El-Shabrawy, 2000).

Table 3. Fermentation characteristics and in vitro $\mathrm{N}$ solubility of alfalfa silage

\begin{tabular}{lccc}
\hline & \multicolumn{3}{c}{ Silage } \\
\cline { 2 - 4 } Item & Untreated & HCHO-treated & Hay \\
\hline No. of sample & 4 & 4 & -- \\
DM (\%) & 33.78 & 33.53 & -- \\
pH & 4.11 & 3.88 & -- \\
Total N (TN), \% DM & 2.92 & 2.94 & -- \\
NPN, \% TN & 43.11 & 34.60 & -- \\
NH 3 -N, \% TN & 7.20 & 5.20 & -- \\
Organic acids (\%): & & & \\
Lactic & 40.33 & 44.82 & -- \\
Acetic & 35.37 & 36.78 & -- \\
Propionic & 14.13 & 14.83 & -- \\
Isobutyric & 2.36 & 0.26 & -- \\
Butyric & 6.56 & 2.61 & -- \\
Isovaleric & 0.66 & 0.16 & -- \\
Valeric & 0.59 & 0.54 & -- \\
Soluble N (\% Total N*) & 72.1 & 30.15 & 46.17 \\
\hline
\end{tabular}

* In borate phosphate buffer solution (El-Shabrawy, 1996).

Table 4. Effect of the experimental diets on digestion coefficients (\%) and nutritive values

\begin{tabular}{lcccc}
\hline & \multicolumn{3}{c}{ Experimental diets } & \multirow{2}{*}{ \pm SE } \\
\cline { 2 - 4 } Item & AH & AS & FAS & \\
\cline { 1 - 4 } Digestibility coefficients (\%): & $64.60^{\mathrm{c}}$ & $67.66^{\mathrm{b}}$ & $72.31^{\mathrm{a}}$ & 0.43 \\
DM & $66.59^{\mathrm{c}}$ & $69.20^{\mathrm{b}}$ & $74.29^{\mathrm{a}}$ & 0.43 \\
OM & $76.31^{\mathrm{b}}$ & $75.07^{\mathrm{b}}$ & $79.26^{\mathrm{a}}$ & 0.44 \\
CP & 66.31 & 67.06 & 66.18 & 0.36 \\
EE & $62.43^{\mathrm{b}}$ & $66.17^{\mathrm{a}}$ & $67.47^{\mathrm{a}}$ & 0.52 \\
CF & $69.35^{\mathrm{c}}$ & $71.23^{\mathrm{b}}$ & $73.18^{\mathrm{a}}$ & 0.43 \\
NFE & & & & \\
Feeding values (\%): & $63.81^{\mathrm{c}}$ & $66.45^{\mathrm{b}}$ & $68.28^{\mathrm{a}}$ & 0.14 \\
TDN & $11.89^{\mathrm{b}}$ & $11.78^{\mathrm{b}}$ & $12.49^{\mathrm{a}}$ & 0.07 \\
DCP & $1.44^{\mathrm{c}}$ & $1.50^{\mathrm{b}}$ & $1.55^{\mathrm{a}}$ & 0.01 \\
NE1* & &
\end{tabular}

* Net energy for lactation calculated according to NRC (1981).

Means within the same row having different superscripts are significantly different $(\mathrm{P}<0.05)$. 
The feeding values expressed as TDN, DCP and NEl followed the same trend of digestibility coefficients. The DCP values were higher $(\mathrm{P}<0.05)$ in diet FAS than diets $\mathrm{AH}$ and AS. The higher DCP with the protection of protein was probably because of higher $\mathrm{CP}$ digestibility.

Certainly the influences on the digestibility of nutrients along the whole alimentary tract are mainly reflections of fermentation in the rumen in terms of availability of $\mathrm{N}$ for rumen microbes as a result of protein protection.

\section{Ruminal parameters:}

The results in Table 5 indicate that the ruminal $\mathrm{pH}$ and total VFA's values did not differ among the tested diets. In contrast, $\mathrm{NH}_{3}-\mathrm{N}$ concentration was higher $(\mathrm{P}<0.05)$ in diet AS than diet AH. The extensive conversion of protein to NPN that occurs during silage fermentation, results in excessive production of $\mathrm{NH}_{3}-\mathrm{N}$ in the rumen, which suggested that conservation of alfalfa as silage may reduce ruminal protein escape, synthesis of microbial $\mathrm{CP}$, or both, relative to conservation of alfalfa hay (Peltekova and Broderick, 1996 and Vagnoni and Broderick, 1997). Ruminal $\mathrm{NH}_{3}-\mathrm{N}$ concentration tended to be lower $(\mathrm{P}<0.05)$ when goats were fed treated silage with formaldehyde than those fed untreated silage diets.

This indicates that dietary rumen undegradable protein (RUP) could be increased without affecting microbial fermentation in the rumen and additional RUP was utilized efficiently (Nagel and Broderick, 1992, Baker et al., 1996 and El-Fadaly et al., 2003). The ruminal $\mathrm{pH}$ of goats fed the tested diets was above 6.0, which was identified as critical $\mathrm{pH}$ for maintaining ruminal fiber digestion (Hungate, 1966).

Table 5. Mean effect of feeding the experimental diets on some rumen parameters of Zaraibi goats

\begin{tabular}{|c|c|c|c|c|c|c|c|}
\hline \multirow{3}{*}{ Items } & \multirow{2}{*}{\multicolumn{3}{|c|}{ Experimental diets }} & \multirow{2}{*}{\multicolumn{3}{|c|}{$\begin{array}{l}\text { Sampling time } \\
\text { (hr) }\end{array}$}} & \multirow{3}{*}{$\pm \mathbf{S E}$} \\
\hline & & & & & & & \\
\hline & $\mathbf{A H}$ & $\mathbf{A S}$ & FAS & & $\mathbf{0}$ & 4 & \\
\hline $\mathrm{pH}$ & 6.17 & 6.32 & 6.20 & 0.06 & $6.47^{\mathrm{a}}$ & $5.99^{b}$ & 0.05 \\
\hline $\mathrm{NH}_{3}-\mathrm{N}(\mathrm{mg} / 100 \mathrm{ml} \mathrm{RL})$ & $19.97^{\mathrm{b}}$ & $21.94^{\mathrm{a}}$ & $17.79^{\mathrm{c}}$ & 0.26 & $18.19^{\mathrm{b}}$ & $21.61^{\mathrm{a}}$ & 0.22 \\
\hline VFA (meq./100 ml RL) & 6.49 & 6.61 & 6.55 & 0.22 & $5.90^{\mathrm{b}}$ & $7.20^{\mathrm{a}}$ & 0.18 \\
\hline \multicolumn{8}{|c|}{ Individual volatile fatty $\mathrm{acid}(\mathrm{mol} / \mathbf{1 0 0} \mathrm{mol})$} \\
\hline Acetic acid & $55.00^{\mathrm{c}}$ & $57.00^{\mathrm{b}}$ & $60.00^{\mathrm{a}}$ & 0.41 & $54.33^{\mathrm{b}}$ & $60.33^{\mathrm{a}}$ & 0.33 \\
\hline Propionic acid & $23.00^{\mathrm{b}}$ & $24.00^{\mathrm{a}}$ & $22.00^{\mathrm{c}}$ & 0.15 & $21.67^{\mathrm{b}}$ & $24.33^{\mathrm{a}}$ & 0.12 \\
\hline Butyric acid & $14.00^{\mathrm{a}}$ & $14.00^{\mathrm{a}}$ & $11.00^{\mathrm{b}}$ & 0.18 & $12.40^{\mathrm{b}}$ & $13.60^{\mathrm{a}}$ & 0.14 \\
\hline Acetate / Propionate & $2.39^{\mathrm{b}}$ & $2.37^{\mathrm{b}}$ & $2.73^{\mathrm{a}}$ & 0.02 & 2.52 & 2.48 & 0.02 \\
\hline Act. + But. / propionate & $3.00^{\mathrm{b}}$ & $2.96^{\mathrm{b}}$ & $3.23^{\mathrm{a}}$ & 0.03 & 3.09 & 3.04 & 0.02 \\
\hline
\end{tabular}

Means within the same row having different superscripts are significantly different $(\mathrm{P}<0.05)$.

The highest $\mathrm{pH}$ value (6.47) before feeding, and decreased significantly $(\mathrm{P}<0.05)$ to be 5.99 at 4 hours post-feeding. Robinson and McQueen (1994) observed a similar reduction in $\mathrm{pH}$ after feeding, which might have been due to increasing availability of fermentable substrate after feeding. In contrast, the highest $(\mathrm{P}<0.05) \mathrm{NH}_{3}-\mathrm{N}$ and VFA's values $(21.61 \mathrm{mg} / 100 \mathrm{ml}$ and $7.20 \mathrm{meq} . / 100 \mathrm{ml})$ were obtained after feeding. The pattern of VFA's and $\mathrm{NH}_{3}-\mathrm{N}$ values followed the reverse trend of the obtained 
$\mathrm{pH}$ values at all times (Shafie and Ashour, 1997 and El-Ayek et al., 1999), and reflecting the pattern of fermentation in the rumen. Acetate and propionate concentrations were higher $(\mathrm{P}<0.05)$ on diet $\mathrm{AS}$ than diet $\mathrm{AH}$, but butyrate, acetate to propionate and acetate plus butyrate to propionate were not different $(\mathrm{P}>0.05)$. Treatment of alfalfa silage with $\mathrm{HCHO}$ led to increase acetate and tended to decrease propionate concentrations, therefore, the ratio of acetate to propionate $(\mathrm{A}: \mathrm{P})$ and acetate plus butyrate, to propionate were higher in goats fed FAS than those fed AH or AS. These results are in harmony with the findings of Pires et al. (1997).

\section{Milk yield and its component:}

The results in Table 6 indicated that dry matter intake and body weight gain were similar for all diets. Higher responses for milk and 4\% FCM yields by 12.5 and $14.2 \%$ were found, respectively for goats fed FAS than for goats fed AS, however, the differences were not significant. Nagel and Broderick (1992) showed that milk yield improved by 11.3 for cows fed HCHO-treated alfalfa silage than those fed untreated. Fat, protein, lactose, SNF and TS productions were greater $(\mathrm{P}<0.05)$ on diet FAS than on diet AS. There were no significant differences in yields of milk, protein, lactose, SNF and TS for goats fed AS and AH. On the other hand, 4\% FCM, milk fat yield and fat, TS percentages were higher significantly. The improvement in the milk yield and its components associated with feeding HCHO-treated alfalfa silage might be due to the decreased protein solubility and degradability in the rumen, consequently more ruminal undegradable protein for digestion and absorption in the small intestine was available, thus increased the availability of amino acids in the small intestine (Nagel and Broderick, 1992, El-Ayek et al., 1999 and El-Shabrawy, 2000).

Vagnoni and Broderick (1997) reported that the response of milk protein secretion to RUP was greater for cows fed AS diets than for cows fed AH diets, which partly may explain the higher milk yield and its component of goats fed FAS than those fed $\mathrm{AH}$ in the present study.

The increase of milk fat $\%$ of goats fed FAS may be due to the improvement in ruminal fermentation particularly crude fiber digestibility (Table 4), producing more acetic acid (Table 5), which is the main precursor for milk fat synthesis. Overton et al. (1996) reported that microorganisms might benefit from the increase of ruminal acetate fermentation stimulating synthesis of lipids.

Table 7 presents the effect of feeding the experimental diets on fractions of milk nitrogen. Total nitrogen (TN) content of milk increased when goats were fed HCHOtreated diet. True protein nitrogen, casein nitrogen $(\mathrm{CN})$ and whey-N values took the same trend of $\mathrm{TN}$. On the contrary, using of $\mathrm{HCHO}$ to protect dietary protein decreased non-protein nitrogen (NPN) content of milk, which reflects dietary differences in RUP (Akayezu et al., 1997).

No significant effects $(\mathrm{P}>0.05)$ on $\mathrm{TN}$, true protein-N, NCN, CN, and whey-N contents were found between animals fed AS and those fed $\mathrm{AH}$, but $\mathrm{NCN} \%$ and NPN yield were significantly higher with animals fed AS.

The increase in milk protein content corresponded to an increase in true protein content as the NCN, CN and whey-N contents in milk increased. Milk NPN 
concentration has been used as an indicator relative protein to energy intake and efficiency of ruminal N capture (Barry et al., 1978 and Oltner and Wiktorsson, 1983).

Table 6. Mean effect of feeding the experimental diets on dry matter intake, body weight change, production of milk and milk components

\begin{tabular}{lcccc}
\hline & \multicolumn{3}{c}{ Experimental diets } & \multirow{2}{*}{ \pm} \\
\cline { 2 - 4 } Item & $\mathrm{AH}$ & $\mathrm{AS}$ & $\mathrm{FAS}$ & \\
Number of Goats & 6 & 6 & 6 & - \\
DMI (kg/head/day) & 1.700 & 1.700 & 1.700 & -- \\
BW changes (Kg/head/day)* & +1.17 & +1.33 & +1.33 & 0.49 \\
Milk yield (g/day) & $894^{\mathrm{b}}$ & $1038^{\mathrm{ab}}$ & $1168^{\mathrm{a}}$ & 59.21 \\
FCM (g/day) & $831^{\mathrm{b}}$ & $1022^{\mathrm{a}}$ & $1167^{\mathrm{a}}$ & 52.75 \\
Fat & & & & \\
\% & $3.55^{\mathrm{b}}$ & $3.90^{\mathrm{a}}$ & $4.00^{\mathrm{a}}$ & 0.08 \\
g/day & $32^{\mathrm{c}}$ & $40^{\mathrm{b}}$ & $47^{\mathrm{a}}$ & 1.99 \\
Protein & & & & \\
\% & $3.43^{\mathrm{b}}$ & $3.40^{\mathrm{b}}$ & $3.58^{\mathrm{a}}$ & 0.04 \\
g/day & $31^{\mathrm{b}}$ & $35^{\mathrm{b}}$ & $42^{\mathrm{a}}$ & 2.17 \\
Lactose & & & & \\
\% & 4.61 & 4.63 & 4.82 & 0.11 \\
g/day & $41^{\mathrm{b}}$ & $48^{\mathrm{b}}$ & $56^{\mathrm{a}}$ & 3.36 \\
SNF & & & & \\
\% & $8.79^{\mathrm{b}}$ & $8.78^{\mathrm{b}}$ & $9.14^{\mathrm{a}}$ & 0.10 \\
g/day & $79^{\mathrm{b}}$ & $91^{\mathrm{b}}$ & $107^{\mathrm{a}}$ & 5.83 \\
TS & & & \\
\% & $12.34^{\mathrm{c}}$ & $12.68^{\mathrm{b}}$ & $13.14^{\mathrm{a}}$ & 0.08 \\
g/day & $110^{\mathrm{b}}$ & $132^{\mathrm{b}}$ & $153^{\mathrm{a}}$ & 7.68 \\
Ash (\%) & 0.76 & 0.76 & 0.75 & 0.01 \\
\hline D & & &
\end{tabular}

* During the experimental period.

Means within the same row having different superscripts are significantly different $(\mathrm{P}<0.05)$.

Decreasing of NPN and increasing of CN of goat's milk as a result of feeding $\mathrm{HCHO}$ treated diet will improve the yield and properties of cheese made from it. Milk containing high casein ratio produces suitable firm curd and so cheese with good body and texture and raise the yield, while increasing of NPN content in milk retard the rennet action and made weak curd and the resultant cheese has low yield and bad properties (Davis, 1965).

In the present study, residual formaldehyde concentrations in milk from goats fed FAS diet have been found to be negligible (1.6 ppm).

Concentrations of some plasma metabolites are present in Table 8. Plasma urea-N was lower $(\mathrm{P}<0.05)$ when $\mathrm{HCHO}$-treated silage was fed, whereas plasma total protein and albumin were higher. Plasma globulin concentration and albumin to globulin ratio were unaffected significantly $(\mathrm{P}>0.05)$ among diets. Plasma urea-N concentration in this present study followed a pattern similar to milk NPN concentration (Table 7).

The lower in blood urea-N and higher total protein and its fractions for goats given diet containing protected protein (FAS) may be due to the increase in RUP, consequently decreased $\mathrm{NH}_{3}-\mathrm{N}$ concentration (Table 5) in rumen liquor, which 
consequently utilized efficiency (Bremmer et al., 1997, Titgameyer and Shirley, 1997 and El-Shabrawy, 2000). Generally, all values were within the normal ranges for healthy goats.

Table 7. Mean effect of feeding the experimental diets on fractions of milk nitrogen

\begin{tabular}{|c|c|c|c|c|}
\hline \multirow[b]{2}{*}{ Item } & \multicolumn{3}{|c|}{ Experimental diets } & \multirow[t]{2}{*}{$\pm \mathrm{SE}$} \\
\hline & $\mathrm{AH}$ & AS & FAS & \\
\hline \multicolumn{5}{|l|}{ Total-N } \\
\hline$\%$ & $0.537^{\mathrm{b}}$ & $0.532^{\mathrm{b}}$ & $0.561^{\mathrm{a}}$ & 0.006 \\
\hline $\mathrm{g} /$ day & $4.80^{\mathrm{b}}$ & $5.52^{\mathrm{ab}}$ & $6 ., 55^{\mathrm{a}}$ & 0.339 \\
\hline \multicolumn{5}{|l|}{ True protein-N } \\
\hline$\%$ & 0.495 & 0.489 & 0.531 & 0.010 \\
\hline g/day & $4.43^{b}$ & $5.08^{\mathrm{b}}$ & $6.20^{\mathrm{a}}$ & 0.287 \\
\hline$\%$ of total-N & 92.19 & 91.92 & 94.66 & 1.560 \\
\hline \multicolumn{5}{|l|}{ Non-protein-N } \\
\hline$\%$ & $0.042^{\mathrm{a}}$ & $0.043^{\mathrm{a}}$ & $0.030^{\mathrm{b}}$ & 0.001 \\
\hline g/day & $0.38^{\mathrm{b}}$ & $0.45^{\mathrm{a}}$ & $0.35^{\mathrm{b}}$ & 0.026 \\
\hline$\%$ of total-N & $7.81^{\mathrm{a}}$ & $8.07^{\mathrm{a}}$ & $5.34^{\mathrm{b}}$ & 0.265 \\
\hline \multicolumn{5}{|l|}{ Non-casein-N } \\
\hline$\%$ & $0.117^{\mathrm{a}}$ & $0.101^{\mathrm{b}}$ & $0.108^{b}$ & 0.003 \\
\hline g/day & 1.046 & 1.048 & 1.261 & 0.067 \\
\hline \multicolumn{5}{|l|}{ Casein-N } \\
\hline$\%$ & $0.420^{\mathrm{b}}$ & $0.431^{\mathrm{b}}$ & $0.458^{\mathrm{a}}$ & 0.007 \\
\hline g/day & $3.75^{\mathrm{b}}$ & $4.47^{\mathrm{b}}$ & $5.29^{\mathrm{a}}$ & 0.280 \\
\hline$\%$ of total-N & $78.21^{\mathrm{b}}$ & $81.02^{\mathrm{a}}$ & $80.75^{\mathrm{a}}$ & 0.722 \\
\hline$\%$ of true protein-N & $84.84^{\mathrm{a}}$ & $88.14^{\mathrm{a}}$ & $85.31^{\mathrm{a}}$ & 2.012 \\
\hline \multicolumn{5}{|l|}{ Whey-N } \\
\hline$\%$ & $0.075^{\mathrm{a}}$ & $0.058^{\mathrm{b}}$ & $0.073^{\mathrm{a}}$ & 0.006 \\
\hline $\mathrm{g} /$ day & $0.671^{\mathrm{b}}$ & $0.602^{\mathrm{b}}$ & $0.911^{\mathrm{a}}$ & 0.062 \\
\hline$\%$ of total-N & $13.98^{\mathrm{a}}$ & $10.90^{\mathrm{b}}$ & $13.90^{\mathrm{ab}}$ & 0.760 \\
\hline$\%$ of true protein-N & $15.16^{\mathrm{a}}$ & $11.86^{\mathrm{b}}$ & $14.69^{\mathrm{ab}}$ & 0.790 \\
\hline
\end{tabular}

Means within the same row having different superscripts are significantly different $(\mathrm{P}<0.05)$.

Table 8. Mean values of blood constituents concentrations of goats fed the different experimental diets

\begin{tabular}{|c|c|c|c|c|c|c|c|}
\hline \multirow[t]{2}{*}{ Items } & \multicolumn{3}{|c|}{$\begin{array}{l}\text { Experimental } \\
\text { diets }\end{array}$} & \multirow[t]{2}{*}{$\pm \mathrm{SE}$} & \multicolumn{2}{|c|}{$\begin{array}{l}\text { Sampling time } \\
\text { (hr) }\end{array}$} & \multirow[t]{2}{*}{$\pm \mathrm{SE}$} \\
\hline & $\mathrm{AH}$ & AS & FAS & & 0 & 4 & \\
\hline Urea-N (mg/100 ml) & $23.72^{\mathrm{a}}$ & $22.60^{b}$ & $20.16^{\mathrm{c}}$ & 0.17 & $22.49^{\mathrm{a}}$ & $21.82^{b}$ & 0.14 \\
\hline Total protein $(\mathrm{g} / 100 \mathrm{ml})$ & $6.62^{\mathrm{b}}$ & $7.06^{\mathrm{b}}$ & $7.68^{\mathrm{a}}$ & 0.16 & 7.10 & 7.14 & 0.13 \\
\hline $\operatorname{Albumin}(\mathrm{g} / 100 \mathrm{ml})$ & $3.78^{\mathrm{b}}$ & $4.00^{\mathrm{b}}$ & $4.39^{\mathrm{a}}$ & 0.08 & 4.04 & 4.07 & 0.07 \\
\hline Globulin $(\mathrm{g} / 100 \mathrm{ml})$ & 3.01 & 3.06 & 3.29 & 0.11 & 3.05 & 3.18 & 0.09 \\
\hline $\mathrm{A} / \mathrm{G}$ ratio & 1.26 & 1.31 & 1.34 & 0.04 & 1.33 & 1.28 & 0.03 \\
\hline
\end{tabular}


It could be concluded that formaldehyde treatment effectively improved utilization of nutrients in alfalfa silage by lactating goats based on better fermentation characteristics during ensiling and in the rumen and improved feeding values. In addition, formaldehyde treatment could be recommended for the alfalfa silage to improve milk production and its components.

\section{REFERENCES}

Abou-Raya, A.K., 1967. Animal and Poultry Nutrition. $1^{\text {st }}$ Edit. Pub. Dar-El-Maarif, Cairo.

Akayezu, J.M., W.P. Hansen, D.E. Otterby, B.A. Crooker and G.D. Marx, 1997. Yield response of lactating Holstein dairy cows to dietary fish meal or meat and bone meal. J. Dairy Sci., 80:2950.

A.O.A.C., 1980. Official Methods of Analysis. Association of Official Analytical Chemists. $13^{\text {th }}$ Ed., Washington DC, USA.

Atwal, A.S., S. Mahadevan, and M.S. Wolynetz, 1995. Increased milk production of cows in early lactation fed chemically treated soybean meal. J. Dairy Sci., 78:595.

Baker, M.J., H.E. Amos, A. Nelson, C. Williams and M.A. Froetschel, 1996. Undegraded intake protein effects on milk production and amino acid utilization by cows fed wheat silage. Can. J. Anim. Sci., 76:367.

Barry, T.N., J.E. Cook and R.J. Wilkins, 1978. The influence of formic acid and formaldehyde additives and type of harvesting machine on the utilization of nitrogen in lucerne silage. 1. The voluntary intake and nitrogen retention of young sheep consuming the silages with and without intraperitoncal supplements of DLmethionine. J. Dairy Sci., (Camb.), 91:701.

Beauchemin, K.A., L.M. Rode and M.V. Eliason, 1997. Chewing activities and milk production of dairy cows fed alfalfa as hay, silage, or dried cubes of hay or silage. J. Dairy Sci., 80:324.

Bremmer, D.R., T.R. Overton and J.H. Clark, 1997. Production and composition of milk from Jersey cows administered bovine somatotropin and fed ruminally protected amino acids. J. Dairy Sci., 80:1374.

British Standard Institution (BSI), 1955. Gerber Method for the Determination of Fat in Milk and Milk Products. B.S.I. Publication No. 696, Part 1 and 2.

Broderick, G.A., 1995. Performance of lactating dairy cows fed either alfalfa silage or alfalfa hay as the sole forage. J. Dairy Sci., 78:320.

Broderick, G.A., D.B. Ricker and L.S. Driver, 1990. Expeller soybean meal and corn by-products versus solvent soybean meal for lactating dairy cows fed alfalfa silage as sole forage. J. Dairy Sci., 73:453.

Conway, E.J. and E. O'Mally, 1957. Micro diffusion methods. Ammonia and urea using buffered absorbents. Biochem. J., 36:655.

Davis, J.G. 1965. Cheese. Vol. 1, J. \& A. Churchill Ltd, London.

Dhiman, T.R., C. Cadorniga and L.D. Satter, 1993. Protein and energy supplementation of high alfalfa silage diets during early lactation. J. Dairy Sci., 76:1945.

Duncan, D.B., 1955. Multiple range and multiple F-test. Biometrics, 11:1-42.

El-Ayek, M.Y., A.Z. Mehrez, S.A. El-Ayouty and H.M. El-Shabrawy, 1999. Influence of source of protein and protection methods on the performance of lactating Friesian cows. J. Agric. Sci. Mansoura Univ., 24(8):3891. 
El-Fadaly, H.A., H.M. El-Shabrawy, M.M. El-Deeb and A.Z. Mehrez, 2003. Effect of formaldehyde treatment of concentrate feed mixture and source of roughage of fermentation and some bacterial activities in the rumen of sheep. The $9^{\text {th }}$ Conf. on Anim. Nutr., Hurghada, 14-17 October. Egyptian J. Nutr. and Feeds (Special Issue):1131.

El-Shabrawy, H.M., 1996. Utilization of dietary protein in ruminants. Solubility and rumen degradability of some proteins and their protection. M.Sc. Thesis, Fac. of Agric., Mansoura Univ., Egypt.

El-Shabrawy, H.M., 2000. Effect of protected proteins on the milk yield. Influence of protecting cotton seed and soybean proteins by either heat or formaldehyde treatments on some metabolic and performance traits of cows. Ph.D. Thesis, Fac. of Agric., Mansoura Univ., Egypt.

Gaines, W.L. and O.R. Overman, 1938. Interrelation of milk fat, milk protein and milk energy yield. J. Dairy Sci., 21:261.

Hristov, A.N., P. Huhtanen, L.M. Rode, S.N. Acharya and T.A. McAllister, 2001. Comparison of the ruminal metabolism of nitrogen from 15-N-labeled alfalfa preserved as hay or as silage. J. Dairy Sci., 84:2738.

Hungate, R., 1966. The Rumen and Its Microbes. Academic Press, New York and London.

Ling, E.R. 1963. A Textbook of Dairy Chemistry. Vol. 2. Practical, $3^{\text {rd }}$ Ed., Champan and Hall, London.

McDonald, P. and R.A. Edwards, 1976. The influence of conservation methods on digestion and utilization of forages by ruminants. Proc. Nutr. Soc., 35:201.

Merchen, N.R. and L.D. Satter, 1983. Changes in nitrogenous compounds and sites of digestion of alfalfa harvested at different moisture contents. J. Dairy Sci., 66:789.

Messman, M.A., W.P. Weiss and M.E. Koch, 1994. Changes in total and individual proteins during drying, ensiling, and ruminal fermentation of forages. J. Dairy Sci., 77:492.

Muck, R.E., 1987. Dry matter level effects on alfalfa silage quality. 1. Nitrogen transformations. Trans. Am. Soc. Agric. Eng., 30:7.

Nagel, S.A. and G.A. Broderick, 1992. Effect of formic acid or formaldehyde treatment of alfalfa silage on nutrient utilization by dairy cows. J. Dairy Sci., $75: 140$.

Naiem, M.A., 1999. Evaluation of methods used for detection of formalin in milk and dairy products. Ph.D. Thesis, Fac. of Agric., Mansoura Univ.

National Research Council (NRC), 1981. Nutrient Requirement of Goats, Angora, Dairy and Meat Goats in Temperate and Tropical Countries. No. 15. National Academy Press, Washington DC.

Oltner, R. and H. Wiktorsson, 1983. Urea concentrations in milk and blood as influenced by feeding varying amounts of protein and energy to dairy cows. Livest. Prod. Sci., 10:457.

Overton, T.R., D.W. Lacount, T.M. Cicela and J.H. Clark, 1996. Evaluation of a ruminally protected methionine product for lactating dairy cows. J. Dairy Sci., 79:631.

Patton, C.J. and S.R. Crouch, 1977. Anal. Chem., 49:464-469. (Cited from Diamond Company, France). 
Peltekova, V.D. and G.A. Broderick, 1996. In vitro ruminal degradation and synthesis of protein on fractions extracted from alfalfa hay and silage. J. Dairy Sci., 79:612.

Peters, T., 1968. Determination of serum total protein. Clin. Chan., 14:1147.

Pires, A.V., M.L. Eastridge, J.L. Firkins and Y.C. Lin, 1997. Effect of heat treatment and physical processing of cottonseed on nutrient digestibility and production performance by lactating cows. J. Dairy Sci., 80:1685.

Robinson, P.H. and R.E. McQueen, 1994. Influence of supplemental protein source and feeding frequency on rumen fermentation and performance in dairy cows. J. Dairy Sci., 77:1340.

SAS, 1996. Statistical Analysis System. Users Guide Statistics. SAS Institute, Cary, North Carolina.

Shafie, M.M. and G. Ashour, 1997. Anticeptazole of the rumen in complementary adaptation to environment. Egypt. J. Nutr. and Feeds, 1:21.

Titgemeyer, E.C. and J.E. Shirley, 1997. Effect of processed grain sorghum and expeller soybean meal on performance of lactating cows. J. Dairy Sci., 80:714.

Vagnoni, D.B. and G.A. Broderick, 1997. Effects of supplementation of energy or ruminally undegraded protein to lactating cows fed alfalfa hay or silage. J. Dairy Sci., 1703.

Van Keulen, J. and B.R. Young, 1977. Evaluation of acid-insoluble ash as a natural marker in ruminant digestibility studies. J. Anim. Sci., 44:282.

Waldo, D.R., J.E. Keys, L.W. Smith and C.G. Gordon, 1971. Effect of formic acid on recovery, intake, digestibility and growth from unwilted silage. J. Dairy Sci., 54:77.

Warner, A.C.I. 1964. Production of volatile fatty acids in the rumen. Methods of measurements. Nutr. Abst. Rev., 34:339.

Webster, D., 1974. Determination of serum albumin. Clin. Chem. Acta, 53:109. (Cited from Bicon Company, Germany).

Woolford, M.K., 1975. Microbiological screening of food preservatives, cold stcrilants and specific antimicrobial agents as potential silage additives. J. Sci. Food Agric., 26:229. 
تقييم دريس وسيلاج البرسيم الحجازى فى العلائق المتكاملة للماعز الحلاب

حامد محمد الثبراوى'، أحمد زكى محرز ، عصام إبراهيم شحاته'

1- معطج بحوث الإتتاج الحيوانس، مركز البحوث الزراعية، وزلرة النزاعة، r - قسم الإنتاج الحيوانس، كلية

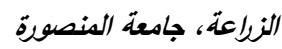

تم حفظ الحشة الثالثة والرابعة للبرسيم الحجازى فى صورة دريس أو سيلاج غير معامل أو معامل

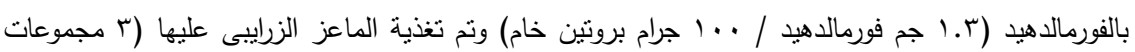

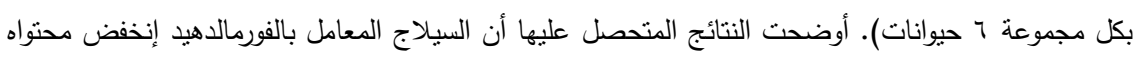

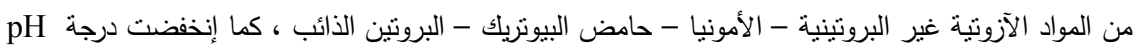

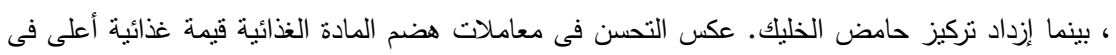

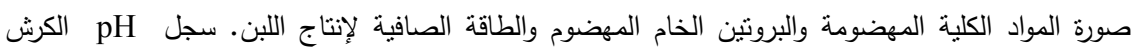

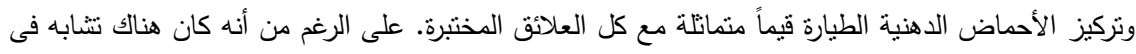

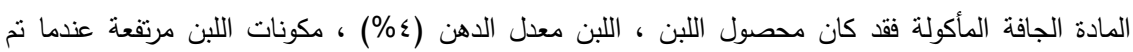

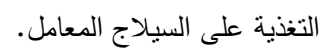
كانت تركيزات المواد الأزوتية غير البروتينية فى اللبن ونتروجين الأمونيا فى سائل الكرش منذفضة بالتغذية

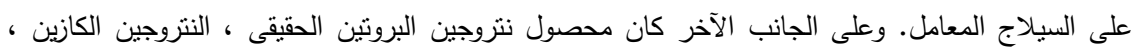

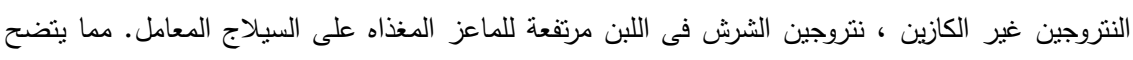

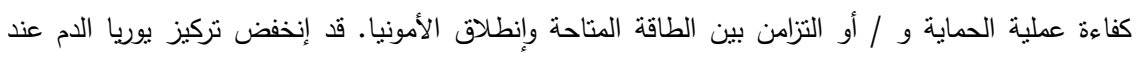

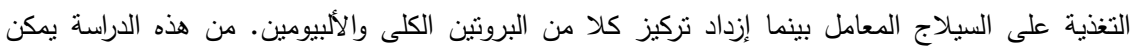

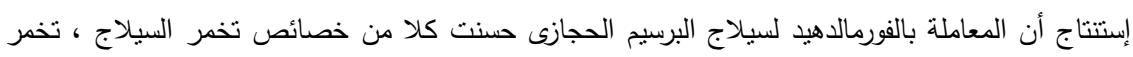

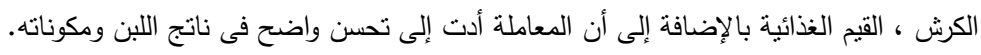

